\title{
THE HOUSE AND GRAVESITE OF CELESTINA
}

\author{
Theodore S. BeardsLey, JR. \\ The Hispanic Society of America
}

In Act I of the Tragicomedia, Parmeno locates and describes the house of Celestina for Calixto: "Tiene esta buena dueña al cabo de la ciudad, allá cerca de las tenerías en la cuesta del río, una casa apartada, medio cayda, pero compuesta e menos abastada" (69-70). The house is not simply Celestina's residence but rather a relatively discreet brothel and house of assignation. Pármeno elaborates: "Muchas encubiertas vi entrar en su casa. Tras ellas hombres descalços, contritos e reboçados, desatacados, que entravan allí a llorar sus pecados" (70-71).

Various other scenes confirm such activities in Celestina's house. The first external reference to the house appears to be that of Amatus Lusitanus (Juan Rodríguez de Castelo-Branco) in his commentary on Dioscorides (Venice, 1553). ${ }^{2}$ Amatus, a former student at Salamanca, notes Dioscorides' praise of the glue manufactured in Rhodes but interposes a new source:

It is well known that glue is made from cowhide. Dioscorides praised that made in Rhodes. But we prize the Spanish glue of Salamanca, made near the river not far. from the house of Celestina, the very famous woman about whom one may read in the Comedy of Calisto and Melibea. $^{3}$

Thus, Pármeno's description (house, river, tannery) springs to life. Amatus (1511-1568) studied medicine at Salamanca in his late teens, returning to Portugal in 1531. We infer then an already established tradition in Salamanca of Celestina as a real person, informing the literary personage, with a real house, the old one, still standing and known to the inhabitants of Salamanca.

At this point, however, we must insert a troublesome dichotomy raised by the text of Celestina. ${ }^{4}$ Pármeno's description of Celestina's house by the tanneries in Act I, Scene 7, uses the present tense "Tiene una casa apartada (...)." But only three scenes later $(I, 10)$ upon encountering the old bawd, he now says "cuando morabas a la cuesta del río, cerca de las tenerías." The new locale remains enigmatic except 
that it appears to be farther away from the home of Pleberio than was the house by the tanneries. ${ }^{5}$ The text also indicates that the new house is more luxurious and implies in the Comedia that the move occurred only two years prior to Celestina's visit to Pleberio's home on behalf of Calixto. Nonetheless, the old house by the tanneries is repeatedly mentioned and alluded to in the text for reasons not necessary to plot and seemingly gratuitous. Indeed, after Celestina's murder, in the new Act XV of the Tragicomedia, Elicia announces her intention to remain in business in the new house, thereby "Jamás perderá aquella casa el nombre de Celestina." But tradition was to decide otherwise.

Barely a decade after Amatus' return to Portugal, a very young Sancho de Muñon (Muñino), "natural de Salamanca" and a student at the university, published his Trajicomedia de Lysandro y Roselia, Llamada Elicia y por otro nombre quarta obra y tercera Celestina (Salamanca: Juan de Junta, 1542). Like the original we are now dealing with a literary treatment, un fingimiento. Nonetheless, the work offers a few curiosities. One protagonist asks another if he has "oído mentar a Celestina la barbuda (...) aquella que vivía a las tenerías" (980). The dialogue goes on to tell us that Elicia has inherited the old house and the profession (including the equipment and supplies) of Celestina, finally in old age even calling herself Celestina. Thus,

jamás perderá aquella casa el nombre de

Celestina ... y muchos extranjeros,

que no conocieron a Celestina, la vieja,

sino de oídas, piensan que es ésta. (981-982)

This lore does not end with just the house and Elicia's continuation of the profession. The play tells us where the original Celestina is buried: "si vas a San Laurencio, junto a la pila de baptizar hallarás sobre su sepultura este epitafio" (983). The epitafio itself, but for its existence, is of little consequence:

Las mientes empedernidas

De las muy castas doncellas,

Aunque más altas y bellas,

De mí fueron combatidas;

$Y$ ablandadas y vencidas

Con mis sabrosas razones,

Pusieron sus corazones

En mis manos ya rendidas.

So color de honestidad

Sembré daños deshonestos,

Armé mis lazos compuestos

Buscada oportunidad,

De cuya perplejidad

Lucrecia no se escapara, 
Con mis promesas cebara

La penelopea bondad.

Si Plutón a mí llamara,

Cien Proserpinas le diera,

Sin que trabajo sufriera,

Aunque más le desdeñara;

Pues si de mí se ayudara

Fedra en su illícito amor,

A Hipólito su dolor

En balde no publicara.

As Menéndez y Pelayo points out "ni la sepultura de Celestina en San Lorenzo, ni su epitafio pueden tomarse en serio," and he adds a significant consideration: "pero son un nuevo documento de la tradición salamantina." 8 Thus, Muñon's Tercera Celestina leaves us with an expanded Salamanca tradition, albeit literary: the continued identification of a specific house by the tanneries in Salamanca attributed to Celestina, an alleged burial site, and a jocose epitaph in verse.

The literary identification of the house is carried forward in the Pelegrino curioso (1577) of Bartholomé de Villalba y Estaña: “ [...] baxaron por la puente, que es larguísima y de ahí dieron en las Tenerias, donde con gran chacota dixo uno de ellos al Pelegrino: 'veis aqui la segunda estacion; esta dicen ser la casa de nuestra madre Celestina, tan escuchada de los doctos y tan acepta, de los mozos tan loada." On the spot, the Pelegrino improvises a new epitaph for Celestina:

Reverenciar se debe la morada

de quien el mundo tiene tal noticia,

mujer que es tan heroyca y encumbrada,

quel discreto no quiere su amicicia.

De todos los estados es loada,

y más de los cursados en milicia,

filosofo dichoso, y bien andante

quien retrató una madre ansí elegante."

Only ten years later, the house appears to have fallen in severe disrepair. Bernardo González de Bobadilla ("Estudiante en la insigne Universidad de Salamanca") in his Primera parte de las Nimphas y Pastores de Henares (Alcalá, 1587) takes a visitor to see the "cosas memorables que hay en Salamanca" which in addition to "la nombrada y poca vistosa torre de Melibea" includes "la derribada casa de la vieja Celestina." Menéndez y Pelayo concluded that by this date the house was "arruinada". But there will be further evidence.

The tradition of epitaph and possible gravesite continues, for a time without the house. Elsewhere we treat at some length three literary treatments of Celestina 
by Francisco de Quevedo. What concerns us here are the opening lines of the first two poems, entitled $A$ Celestina (c. 1601) and $A$ una alcabueta of subsequent but unknown date. Both poems can be considered to be in the tradition of epitaph for Celestina although it does not seem necessary for Quevedo to have known either of the versions of Muñon or Villalba. Indeed, the first Quevedo version has been seen as no more than a good example of the epigram tradition in the style of Martial. ${ }^{10}$ We incline toward the strong possibility of a visit to Salamanca by Quevedo at some time between 1601 and 1603 at which point he would assuredly have been shown the ruins of Celestina's house. ${ }^{11}$

A Celestina begins "Yace en esta tierra fría, digna de toda crianza," and it would be a simple matter to attribute the bic jacet opening as pure literary formula and no more. It becomes more difficult to make such an assumption in the light of the second poem. A subsequent revised and expanded version of his $A$ Celestina appears in an undated manuscript with the title "A una alcahueta que no quiso la Extremaunción." 12 The first two lines of this version clarify and make more precise the meaning of the opening lines of $A$ Celestina: "Yace aquí, sin obelisco/pobre de ofrenda y de cera."

We must recall that Celestina, not likely in a state of grace, called out for "Confesión, confesión!" (II, 111) as she is being murdered. Thus, without the proper ministrations of the church, she could not have been buried in a Spanish cemetery (hallowed ground by definition). Burial options were few, an unmarked grave somewhere in a field or even, perhaps, in her own backyard as it were. If indeed nothing remained of the house, could the site have become in Salamancan tradition the burial plot of a Celestina by now as historical as literary? And to what degree, if any, can the Quevedo poems be viewed as documentation of an attributed gravesite?

The matter of Celestina's house is by no means closed. A curious bilingual dialogue constituting an armchair tour of Spain was published by James Howell in the middle of the seventeenth century. ${ }^{13}$ Having reached the subject of Salamanca, the speakers mention the well-constructed colegios, the Roman bridge, and the bull at the entrance referred to in the Lazarillo. Charles then asks Philip: "Vio vm. alli por ventura la casa de Celestina? [Did you happen to see there the House of Celestina?]." Philip replies: "Señor, bien me apuntaron el lugar adonde estava, mas no tuve tanta curiosidad que fuera a verla, y tambien me parece que es cosa fingida" [Sir, they pointed at the place where it was, but I had not so much curiosity to go and see it, besides, me thinks it is a famed thing . (22-23)].

The terminus ad quem for Howell's knowledge of the existence of Celestina's house appears to be 1624. If we take Howell's statement at face value ("they pointed at the place where it was [... [ but I has not so much curiosity to go and see it"), Howell is only testifying to the tradition of a location for the house but without any first-hand knowledge of its physical state at that time. Conversely, his testimony 
does confirm the survival of the tradition.

As late as the year 1928 we can confirm the demise of the first house but, perhaps surprisingly, not the disappearance of the tradition of its alleged site. Salamanca $y$ sus costumbres was an illustrated monthly journal devoted to the city and only intended to last for one year, an intention achieved with number 12 in December of 1928. The anxious reader only had to wait until issue 7 (July) for Celestina to appear. A full page is given to La peña Celestina, with photographs which are identified as "supervivencia del antiguo y derribado murallón salmantino [fig. 1, p. 130]" The house itself is not mentioned but in leaving the rock, the author reminds us:

Y atrás, lector, dejamos los parajes espisodicos de aquella gran tragedia de Rojas, que si no has leido alguna vez, por lo menos has oído referir. Aún parece propicio este lugar, entre la penumbra del anochecer, para los comadreos de las viejas, las citas secretas de los galanes, los lances de espada o las caídas misteriosas desde esta gran altura ...

Aún nos parece sentir los pasos cautos de Calixto y su figura recatada que espera en un rincón a la vieja Celestina, para ultimar los detalles de una amorosa trapisonda.

Aún nos parece ver la sombra de una débil mujer, cubierta con un antifaz, que marcha entre sollozos, apoyada en el hombro decrépito de una vieja rechoncha.

Aún nos parece oir entre los quejidos débiles, agónicos del galán malaventurado el nombre dulce que sale de sus labios como un suspiro: ¡Melibea!.... ${ }^{14}$

Lest there be any doubt, an article in the final issue of the journal, "Un paseo por la Salamanca antigua," takes us back to the rock [fig. 2, p. 130]: "Este enorme, híspido y escarpado peñasco es la Peña Celestina (que también se llamó Santo Toribio), y se alza sobre la ribera de los curtidores o de las tenerías, donde habitó aquella Celestina ensambladora de voluntades y reconstructora de virginidades que con sus artes originó la tragedia de Calixto y Melibea." 15

How then do we attempt to explain the dilemma of two houses, tradition only accepting the earlier one? Russell gets very close to the point, I think, and is perhaps only missing one detail which does provide a more than plausible reason for the new fictional house of Celestina: "... it seems to me necessary to give serious attention to the hypothesis that the Celestina we think of as a wholly original literary creation may in fact be based on the pre-existing character of a real or legendary Salamancan bawd.believed once to have lived in the house described by the Portuguese doctor. The constant and apparently pointless harping in the text on the exact location of the house in which the bawd used to live becomes entirely explicable if we think of the authors of the book as wishing to establish firmly in the minds of their first readers that the Celestina of their story is based on the character of a real personage 
$(\ldots) . " 16$

At the Celestina conference at Purdue in late 1991, the closing address was given by Professor María Eugenia Lacarra on the subject of "La evolución de la prostitución en la Castilla del Siglo XV." Amidst a wealth of new facts, Dr. Lacarra cited three documents concerning Salamanca dated in 1498 which, in effect, would prohibit Celestina from exercising her profession in the old house. ${ }^{17}$ Those documents alone explain the move, but I suggest there is even more than meets the eye. I agree totally with Professor Russell concerning a real, historical personage on which the literary Celestina is built. Indeed, given other early documents concerning prostitution we think it plausible, if not totally necessary, that the real personage was indeed murdered or died under suspicious circumstances thus providing the first death for the Comedia. In that event, the real Celestina must have died before composition of the Comedia, and in view of the dates of the documents, may well have done so in the old house. By virtue of the decrees, her girls would have been obliged to live elsewhere in Salamanca. Thus in mortis because of actual circumstances at the time, Celestina on stage was obliged to live in a house she never knew in order to accommodate "the all-important sense of actuality given it by the dialogue form and required (...) by the traditions of both Latin and humanistic comedy."18

In any event, tradition steadfastly refuses to acknowledge the new house and, perhaps we might argue, in so doing lends a bit of credence for a real bawd who once lived and possibly died in la vieja casa alli por las tenerias. If so, where is the body buried?

\section{*k*3:}

\section{NOTES}

${ }^{1}$ We cite from the often reprinted, easily accessible, edition of Julio Cejador y Frauca, Fernando de Rojas, La Celestina (Madrid: Espasa-Calpe).

${ }^{2}$ First noted by Doctor Pedro Dias in a Portuguese medical journal (1895) and subsequently by Ricardo Jorge in Nuestro Tiempo 119 (Noviembre 1908), 191-199, cited by Menéndez y Pelayo in Origenes de la novela, II (Santander, 1943), 277. The original citation was rediscovered independently by Juan Ares Montes. See F. Maldonado de Guevara, "La casa de Celestina," Anales cervantinos 7 (1958), 287-288.

3 "Glutinum quod ex bubulo fit corio, notum est, Rhodium Dioscorides laudat: At nos Hispanum Salmanticense, apud pontem paratum non procul a domo Celestinae mulieris famosissimae, et de qua legitur in comoedia Calisti et Melibeae." See Maldonado (note 2 above). I am especially grateful to Professor Ivy Corfis for her bibliographical advice and also to my colleague, Mitchell Codding.

${ }^{4}$ See P. E. Russell, "Why did Celestina Move House?" The Age of the Catholic Monarchs, 1474-1516, eds. A. Deyermond and I. MacPherson (Liverpool UP, 1989), 155-161.

${ }^{5}$ See Dorothy Severin and Joseph T. Snow, "La Casa de Pleberio en Salamanca," 
Celestinesca 12.1 (1988): 55-62.

${ }^{6}$ We cite from the edition of Manuel Criado de Val in Las Celestinas (Barcelona: Planeta, 1976).

7 "La parroquia de San Lorenzo en Salamanca se halla extramuros" (Criado de Val, p. 983). The location was appropriate for the real site of the alleged house of Celestina, even in Pármeno's description placing it "al cabo de la ciudad."

${ }^{8}$ Origenes de la novela, II, 278.

${ }^{9}$ Origenes, 278-279.

"See Anthony Giulian, Martial and the Epigram in Spain in the Sixteenth and Seventeenth Centuries (Philadelphia, 1930), pp. 52-55.

"In the spring of 1601, Quevedo abandoned his studies at Alcala and by the summer was in residence in Valladolid where he would remain until after September of 1603 when he had already given $A$ Celestina to Pedro de Espinosa for his anthology, Flores de Poetas Ilustres de Española (Valladolid, 1605). See Luis Astrana Marín, La vida turbulenta de Quevedo (Madrid, 1945).

12 The manuscript in question is entitled Fragmentos no impresos basta oy. De Don Francisco de Quevedo (Biblioteca Menéndez y Pelayo, Santander, Ms. 108). Both $A$ Celestina and Alcabueta are reproduced in Volume $\mathrm{I}$ of the Obras completas edited by José Manuel Blecua (Barcelona, 1968), 1146 and 1148.

${ }^{13}$ A Welshman, Howell graduated from Oxford (1613) and a few years later was sent by his employer on a business trip to the continent (including Spain) where he lingered until 1622. Late that year he was sent to Madrid by a new employer, returning in 1624. There is no record of a subsequent trip to Spain. We cite from a rare copy in The Hispanic Society of America (126/H83) without place or date of publication: J.(ames) H.(owell), La Perambulaciön de España, y de Portugal; en un Discurso entre Carlos y Felipe/The Perambulation of Spain and Portugal; In a Discours 'twixt Charles and Phillip: Which may serve for a Directory How to Travel through those Countreys (1645?).

14 Antonio Sánchez González, "La Peña Celestina," Salamanca y sus costumbres 7 (julio, 1928), pp. 12-13.

${ }^{15}$ Vicente Marcos, "Un paseo por la Salamanca antigua," Salamancay sus costumbres, 12 (diciembre, 1928), p. 17.

${ }^{16}$ P. E. Russell, pp. 159-160.

${ }^{17}$ María Eugenia Lacarra, "La evolución de la prostitución en la Castilla del Siglo XV," in Fernando de Rojas and Celestina: Approaching the Fifth Centenary, eds. I. A. Corfis and J. T. Snow (Madison: HSMS, 1993), pp. 61-64.

${ }^{18}$ Russell, p. 160. 


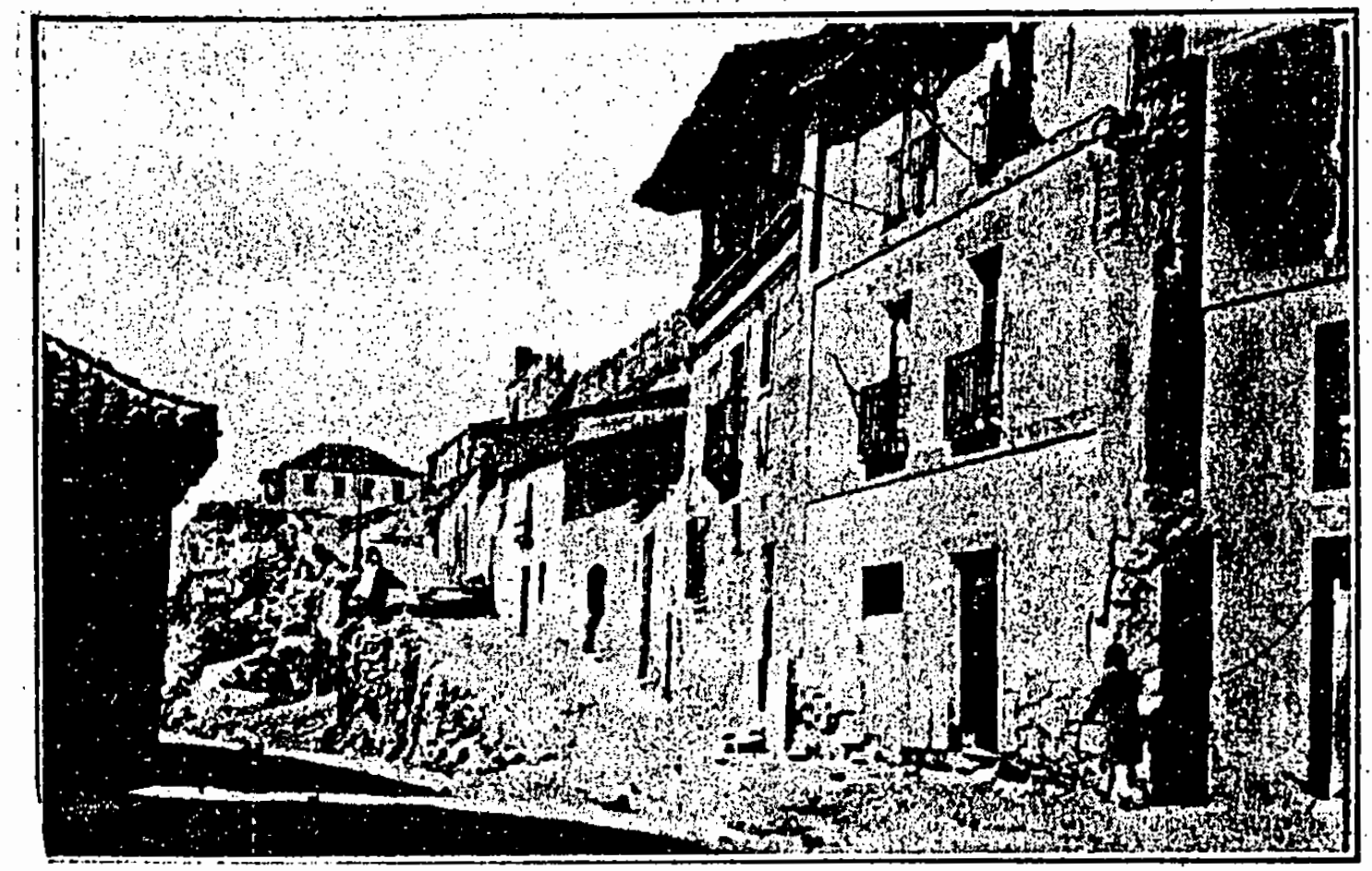

Calle de San Juan de Alcázar y Peña Celestina.

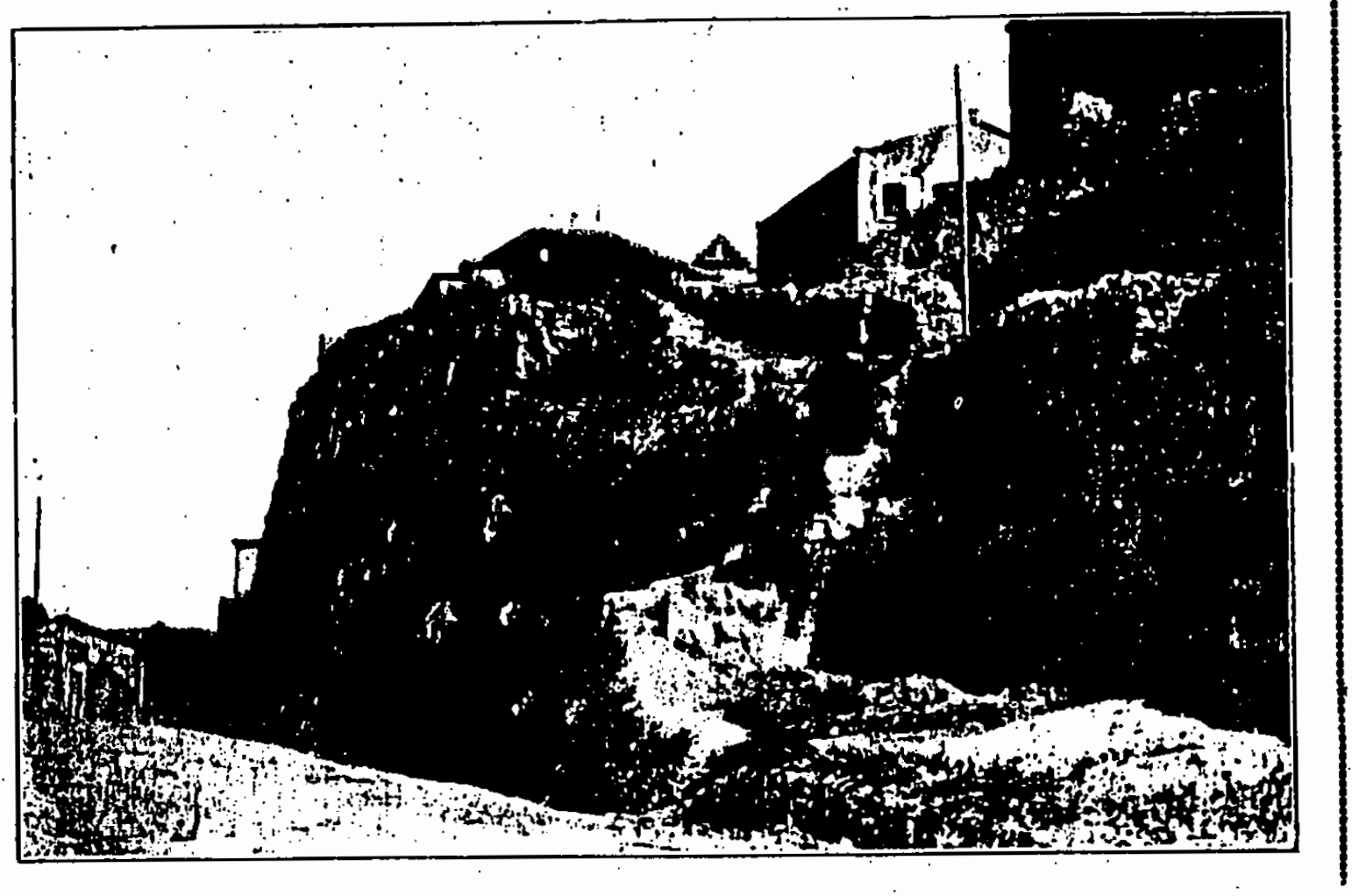

Peña Celestina 